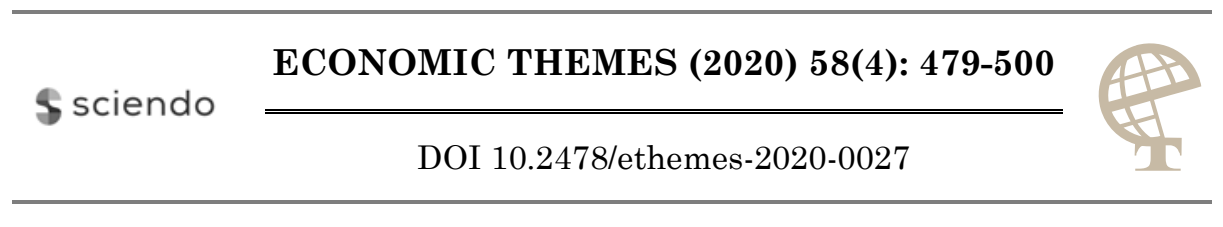

\title{
EMERGING MARKETS AND INTERNATIONALIZATION OF RETAIL: THE CASE OF BRIC COUNTRIES
}

\author{
Svetlana Sokolov Mladenović \\ Faculty of Economics, University of Niš, Serbia \\ $\bowtie$ svetlana.sokolov@eknfak.ni.ac.rs \\ Igor Mladenović \\ Faculty of Economics, University of Niš, Serbia \\ $\triangle$ igor.mladenovic@eknfak.ni.ac.rs \\ Marija Petrović Ranđelović \\ Faculty of Economics, University of Niš, Serbia \\ $\triangle$ marija.petrovic@eknfak.ni.ac.rs
}

UDC

339.13.025.87

Review

paper

\begin{abstract}
The main purpose of this paper is to investigate the relationship between the emerging markets and retail internationalization, with a special focus on the markets of Brazil, Russia, India and China, also known as BRIC countries. The paper relies on the fact that the emerging markets, especially the markets of BRIC countries, have recently attracted an increasing attention of the scientific and professional community, as well as international retail companies. After the economic crisis in 2008, the internationalization of retail, as a key business strategy, is changing its direction and form, in order to focus on the emerging markets. Based on the available secondary data sources considering the operations of the largest international retail companies and the attractiveness of the emerging market from 2014 to 2018, we test the hypotheses set in this research. One of the key hypotheses is that a certain number of international retail companies present on the BRIC country market is determined by its ranking on the list of the most attractive markets. We test this hypothesis by constructing a simple regression model for each country individually. Another key hypothesis is that the ranking of a BRIC country on the list of the most attractive
\end{abstract}

This paper is the result of research on obligations under the Agreement on the Implementation and Financing of the Scientific Research in 2020 (registration number 451-03-68/202014/200100) concluded between the Ministry of Education, Science and Technological Development of the Republic of Serbia and the Faculty of Economics, University of Niš 
markets is the result of various factors. We test this hypothesis using the method of descriptive statistics for each country individually. The obtained research results have economic validity and they fill a scientific niche in the research of the relationship between the attractiveness of the BRIC market and the internationalization of retail. In addition, the obtained results represent the basis for further research of this issue,

Received: 29.06.2020 Accepted: 29.09.2020 given the large-scale changes caused by the global coronavirus pandemic.

Keywords: emerging markets, BRIC, retail internationalization, GRDI, market attractiveness, country risk, market saturation.

JEL classification: L80, L81

\section{Introduction}

The emerging markets have been one of the key words in theoretical and methodological research since 2000. The increased interest of the scientific and professional community in this topic is a direct consequence of the changes in the balance of power on the international market. In the managerial context, the term emerging market first appeared in the 1980s, in order to be more precisely defined some twenty years later, with a more detailed systematization of the countries belonging to this group. However, the emerging markets are not only a topic for the scientific research; they are far more than that, given their growing importance for the business expansion of companies from different sectors, including trade (retail in particular). Retail companies are constantly challenged to change their business strategies and policies, with internationalization being one of the key strategies, changing the direction and form of retail internationalization, especially after the economic crisis in 2008. Due to the high degree of saturation of a number of markets, international retail companies see the emerging markets as target markets. These facts gave rise to the research idea in this paper, which sets the relationship between the emerging markets, with a focus on BRIC countries, and the internationalization of retail as its subject. In addition, the review of relevant literature and previous research results show the lack of a comprehensive comparative analysis of the markets of BRIC countries and their connection with retail internationalization. The aim of the paper is to investigate the relationship between these two current topics, in order to test one of the key hypotheses in the paper, i.e. that the number of international retail companies on one BRIC market is determined by its attractiveness. The paper is divided into theoretical and practical part. The theoretical part, through literature review, points out the key theoretical views on the emerging markets, on the one hand, and retail internationalization, on the other. The practical part, based on the available secondary data, focuses on the research conducted, using the model of simple regression analysis and descriptive statistics, in order to test hypotheses and draw appropriate conclusions, emphasizing the contribution of this research and its limitations. 


\section{Literature review}

\subsection{Emerging markets}

In the last 20 years, the emerging markets have attracted enormous attention of theorists and practitioners. As a result, a large number of studies have appeared that approach this topic from different aspects, connecting it with current economic and social events. In doing so, we notice a macro and micro approach to the emerging market issues (Khanna and Palepu, 1997; O’Neill, 2001; Wright et al., 2005; Meyer et al., 2009; Paul and Benito, 2018).

The term emerging market was first used in 1981 by Antoine van Agtmael, a World Bank economist, to describe the rapidly growing economies of the so-called Third World countries (Van Agtmael, 2007). These countries, former colonies, did not belong to either the bloc of capitalist economies (USA and Western European countries) or the communist bloc (Russia, China, Cuba and the countries of Eastern Europe). In different historical periods, different economies have been described as emerging, since this term suggests the phase through which the economy should go on its way to a developed or an industrialized economy. For example, Hong Kong, Singapore, South Korea and Taiwan were often cited as emerging economies in the 1980s, and sometimes as "Asian Tigers".

Due to the growing interest of the scientific and professional community in the emerging markets, during the 1990s and 2000s, the acronyms: BRIC - Brazil, Russia, India and China, MINT - Mexico, Indonesia, Nigeria and Turkey, NEXTELEVEN - Bangladesh, Egypt, Indonesia, Iran, South Korea, Mexico, Nigeria, Pakistan, the Philippines, Turkey, and Vietnam started to be used, emphasizing the importance of economies that "promised" high return on investment (Aulakh et al., 2000; Siegel, 2009; Sandberg, 2014; Alon et al., 2010; Paul, 2015).

So, the emerging markets mainly refer to the economies of low and middle income countries, which in recent years have had rapid economic growth, spurred by the comparative advantages of a huge base of cheap, but increasingly educated labor force, as well as the inflow of foreign capital and technology (Corporate Finance Institute, 2020). Because of their rapid growth potential, the emerging markets give significant investment opportunities, but also often present challenges, including underdeveloped infrastructure, difficulties in obtaining reliable information, corruption, and the need to manage government bureaucracies.

The emerging markets, also known as emerging economies or developing countries, are countries that invest in more productive capacity. For this reason, they gradually distance themselves from their concepts of traditional economies, due to years set on on the development of agriculture and the export of raw materials. The practice shows that these countries are rapidly industrializing and accepting the concept of the free market or the mixed economy. 
Despite its relatively short history, the emerging markets have become the subject of numerous empirical studies. The insights into broader literature, empirical studies and theoretical considerations and research of the emerging markets point to two different directions or schools of thought, and these are, above all, the institutional and the economic school of thought on the emerging markets (Iwasaki, 2020).

One of the members of economic school of thought is Hoskinson (2000), who, with his associates defines the emerging market as "a country that meets two conditions: rapid economic development and government policy that favors economic liberalization and the acceptance of the free market system". This definition significantly relies on the interpretation of the emerging markets presented by Arnold and Quelch (1998), suggesting that these are low and middle income countries in the process of economic liberalization, with a growth rate higher than $5 \%$ of average annual GDP. Wright et al. (2005) upgrade this definition, in the sense that the emerging markets include unique economic, social, and political determinants.

The second group of theories, definitions and interpretations, which theoretically and practically helped to conceptualize the emerging market research, belongs to the institutional school of thought. One of the first representatives of this school is Khanna and Palepu (1997), who claim that the emerging markets offer the prospect of significant economic growth, as they develop the necessary institutional foundations to stimulate trade, but with certain institutional gaps that may cause the market failures. Furthermore, Peng (2003) points out that the emerging markets are characterized by the so-called institutional transition from central planning to an increasingly widespread market competition. Meyer et al. (2009) add up to these definitions and state that institutional frameworks on the emerging markets differ greatly from those on developed markets.

The analysis of theoretical concepts of the economic and the institutional schools of thought on the emerging markets points to the key elements typical of both. Thus, the economic school of thought is dominated by the economic elements in the interpretation and the analysis of emerging markets, namely: 1) economy (economic growth, economic growth potential, unstable macroeconomic environment, lower levels of economic development), 2) liberalization (economic and market reforms, underdeveloped markets for products and services, increased foreign direct investment, factor-driven economy, orientation towards innovationbased economy), 3) income levels (low or middle income, GDP per capita growth, middle class and living standard growth, poverty and inequality reduction at the income level). The institutional school of thought is dominated by the institutional elements, namely: 1) differences in terms of institutional gaps, the level of uncertainty and risk, culture, urbanization and resource constraints, and 2) the transition of institutions. 
In addition to these characteristics, according to the World Bank (2020), in order for a country to be declared as an emerging market, it must meet the following conditions:

1. Per capita income lower than average, which is the first important criterion, because it encourages the second characteristic, rapid economic growth. In this context, the leaders of these countries take various actions to accelerate the changes in the transition to industrialized economies. According to the World Bank, these markets have a per capita income of 3995 dollars and less.

2. Accelerated economic growth. For example, in 2019 the economic growth of the most developed countries, such as the USA, Germany and Japan, was less than 3\%, while the economic growth in Egypt, Poland, India and Malaysia was $4 \%$, and in China and Vietnam between 6 and $7 \%$.

3. High instability, as a consequence of the first two characteristics. In addition, it can occur as a result of natural disasters, shocks caused by external prices and instability of the domestic currency. Specifically, economies that traditionally rely on agriculture are particularly vulnerable to disasters, as was the case with the earthquake in Haiti, tsunami in Thailand or drought in Sudan. However, these natural disasters can also set the stage for further commercial development, as was the case in Thailand.

4. Sensitivity to exchange rate changes, especially in the foreign trade of countries in which the foreign exchange clause is linked to the US dollar. In addition, these countries are sensitive to the lack of stocks of certain goods, such as oil and food, as they do not have enough power to influence these changes. Additionally, when the emerging market leaders take the measures necessary for industrialization, a number of population layers suffer, such as farmers, who may lose land. This can lead to a social unrest and riots over time.

5. Growth potential, which requires a lot of investment capital. However, the capital markets of these countries are less mature than developed ones; they do not have solid results from foreign direct investment and it is often difficult to get information about companies listed on their stock exchange markets. All these characteristics increase the risk, but those who take it can expect a higher return on investment compared to the average. Additional reason is that many of these countries, lacking demand, focus on an export-oriented strategy, so they produce cheaper consumer goods and goods for developed markets. It is these characteristics that make the emerging markets attractive to investors, provided that they have a low debt, a growing labor market and a government that is not corrupt.

According to MSCI (2020), emerging markets make up a list of 26 countries: Argentina, Brazil, Chile, China, Colombia, the Czech Republic, Egypt, Greece, Hungary, India, Indonesia, Korea, Malaysia, Mexico, Pakistan, Peru, the Philippines, Poland, Qatar, Russia, Saudi Arabia, South Africa, Taiwan, Thailand, 
Turkey and the United Arab Emirates. This category also includes Argentina, Hong Kong, Jordan, Kuwait, Saudi Arabia, Singapore and Vietnam.

Theoretical and practical discussions on the emerging markets list China and India as countries with the greatest growth potential. Moreover, GDP of both countries amounts to about 28.1 billion USD, which is significantly higher than in the USA or the EU. Also, these two countries have 35\% of the world's labor force and population.

In addition to China and India, the analyses of the emerging markets most often refer to Brazil and Russia, i.e. BRIC countries, which will be the subject of the analysis in this paper.

\subsection{Internationalization of retail}

Internationalization has played a key role in the business strategy of retail companies for more than 30 years. The literature in the fields of trade and trade management has accepted a view that a retail company goes international when it reaches a critical size on the domestic market, and due to legal restrictions, can no longer grow. So, due to the high degree of saturation of the domestic market, large retail chains invest abroad to find new sources to generate profit. However, there are different opinions. Alexander and Doherty (2009) point out that "internationalization for many retail companies is no longer a logical consequence of limited domestic market growth opportunities, but a chance to expand their business on the global market, where their product and service range will be valued by a wider circle of customers". On the other hand, the practice confirms that foreign market entry is most successful when it is consistent with the key advantage of a retail company. These can be the following: low cost and operational efficiency (Wal-Mart, Carrefour, Aldi), strong brands (Starbucks), fashion reputation (H\&M, Zara) or dominance in a category (IKEA). Successful international retail chains recognize the specifics of the country they come to and adapt to them. Global culture is reflected in the recognizable organizational and personnel characteristics of the international company, as well as in the rapid development of local management and its implementation of the "global corporate culture" (Ćuzović et al., 2019).

As a research area, internationalization has attracted the attention of a number of researchers since the 1980s. In the last 20 years, the research on this topic has become quite intensive, to divide it into three large groups, each of which with a theoretical and practical contribution to studying retail internationalization (Alexander \& Doherty, 2010). The first group of studies focuses on various aspects of the international activity of retail chains, such as the motives of the internationalization process, the choice of target markets and entry methods, as well as the choice of sales strategy. The second group of research conceptualizes the process of internationalization, pointing out the specifics of the international 
experience of retail chains and the value this experience provides to understand the international business processes. The third group of research analyzes issues from the perspective of different research methodologies.

All these groups offer different approaches to defining retail internationalization. One of the authorities in this field, Dawson (2007), points out that retail internationalization includes classic and online sales facilities of a retail company in foreign countries, as well as the process by which its business and managerial knowledge expands abroad, as a result of slow growth and saturation on the domestic market. Furthermore, Dawson (2007) suggests the application of two basic criteria for assessing the level of retail internationalization: the number of countries in which the retail company operates and the share of sales volume on international markets in total sales volume. Accordingly, he comes to several key conclusions important for retail internationalization, namely: 1) the share of international retail companies in the total number of companies, in terms of sales volume increases, 2) the largest retail companies increasingly expand their business beyond the national market, and 3 ) the share of sales generated on international markets in the total sales volume of retail companies increases.

Alexander \& Doherty (2010) give a broader view in relation to Dawson, and argue that "the internationalization of retail involves the diffusion of certain retail concepts and formats onto new, foreign markets, as well as the internationalization of managerial roles and technology". This interpretation is largely based on the Vida and Fairhurst (1998) views, who develop a retail internationalization model as a theoretical basis for future research in this area. The model includes previous research, processes and results arising from the international expansion of retail companies, suggesting that the characteristics of the company and its management are the two leading factors in deciding on the internationalization process. Furthermore, these characteristics can be divided into five elements: 1) competitive advantage, 2) international knowledge, 3) international experience, 4) management attitudes and 5) the size of the retail company. According to these authors, the internal company factors are decisive in the process of its business internationalization.

Given the definitions presented above, we may point to their common characteristics, reflected in the following (Ćuzović et al., 2015):

- Retail internationalization is a transfer of knowledge, concepts and business formats;

- Retail internationalization implies doing business on two or more different international markets;

- Retail internationalization enables overcoming linguistic, cultural, sociological and legal barriers in communication between the two countries;

- Retail internationalization enables the business expansion beyond national markets and finding new sources for generating profit;

- Internationalization is a complex process, not a series of events. 
Thus, all research on the issue of retail internationalization points to several key topics that have attracted and still attract the attention of researchers, namely (Alexander et al., 2011; Burt et al., 2016; Mohr \& Batsakis, 2016): internationalization drivers and obstacles, performance and strategy that includes speed, foreign market selection, foreign entry mode and employment strategy. These topics can be seen in Figure 1.

Figure 1. Key areas of RI research

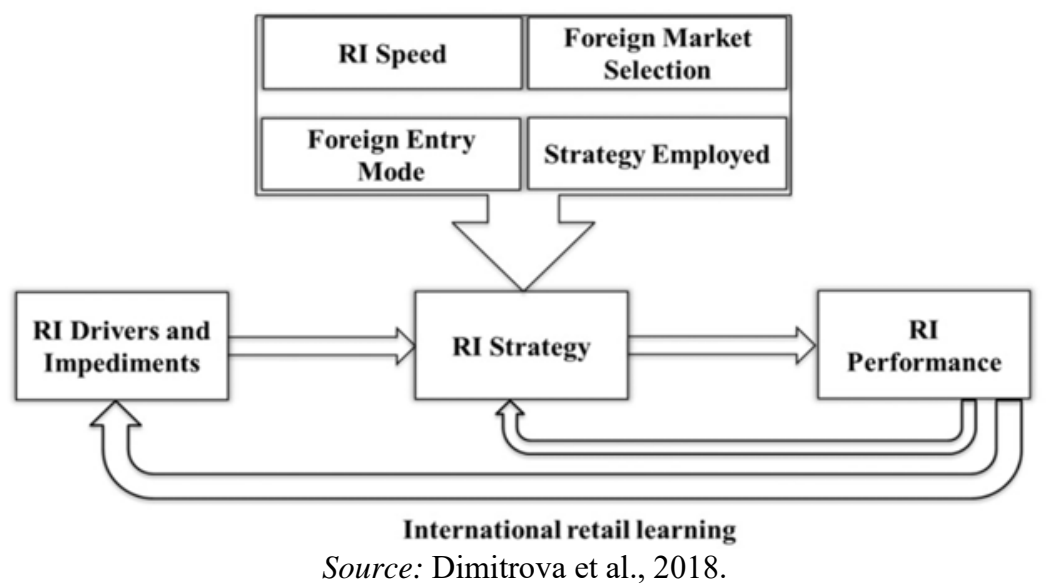

A significant shift in the research of retail internationalization, largely conditioned by the implementation of this strategy by retail companies, occurred after the financial crisis in 2008 (Pederzoli \& Kuppelwieser, 2015). Thus, numerous analyses confirm that, contrary to expectations, the pace of internationalization has increased, with a different direction. It is evident that the behavior of international retailers, i.e. the pattern of retail internationalization, has changed. Retail internationalization strategies are gradually focusing on former communist countries entering the world market. In other words, the so-called emerging markets, discussed in previous sections, come to the stage. However, not all emerging markets are equally interesting for international retail companies, as business growth on these markets is not always linear. On the other hand, the research on the emerging market and retail internationalization relations is well focused on individual countries (Bianchi, 2009; Hu, 2018; Amine \& Lazzaoui, 2011) or one business segment of international retail companies (Diallo \& Siqueira, 2017; Gomez et al., 2018; Paul, 2020). There is a certain niche in the research of this issue, in the sense that there is no comprehensive analysis of the growing importance of emerging markets, especially BRIC countries, for the process of internationalization of retail companies. In other words, previous research has not sufficiently engaged in a comparative analysis of the attractiveness of the BRIC market in a certain time interval, to point to different importance of individual 
countries in the process of retail internationalization, and, thus, reveal the reason for the varying presence of international retail companies on the markets of these countries. Considering the abovementioned, the question arises whether the attractiveness of one market is a factor that affects the presence of international retail companies. The aim of this paper is to fill a scientific niche in the research of relationship between the emerging markets, with a special focus on the BRIC countries and retail internationalization, in terms of analyzing the market attractiveness and the presence of international retail companies, as well as the factors that affect this attractiveness.

\section{Research methodology}

\subsection{Data and methods}

For the purposes of research in this paper, we use secondary data sources. This data, published by Deloitte Touche, a consulting company, relates to the world's largest retail companies in terms of sales volume. A report entitled Global Power of Retailing, covering the period from 2014 to 2018, is used for the analysis. We use this data to assess the achieved level of retail internationalization in Brazil, Russia, India and China, i.e. the presence of international retail companies in these countries, based on a comparative analysis. Furthermore, in order to assess the attractiveness of BRIC countries, we use data on the global market attractiveness, published by A.T. Kearney, a consulting company. A report entitled GRDI (Global Retail Development Index), covering the period from 2014 to 2018, is used for the analysis. ${ }^{2}$ Based on the data in these reports, we test the following hypotheses:

H1: International retail companies have had varying presence on the markets of BRIC countries in recent years.

$\mathrm{H} 2$ : The markets of BRIC countries have different degrees of attractiveness in the time interval from 2014 to 2018.

H3: The number of international retail companies on one BRIC country market depends on its attractiveness.

H4: Various factors affect the attractiveness of BRIC countries for international retail companies.

\subsection{Research results and discussion}

Based on the available secondary data, which refer to the largest retail companies and their operations by years (2014-2018), we first point to their presence in BRIC countries, as the most important segment of the emerging market. In this way we

${ }^{2}$ For 2018 we use data A.T. Kearney published in 2019. 
test the first hypothesis. Figure 2 presents the number of international retail companies on the markets of Brazil, Russia, India and China.

Figure 2. Number of international retail companies in the list of top 250 on BRIC markets (2014-2018)

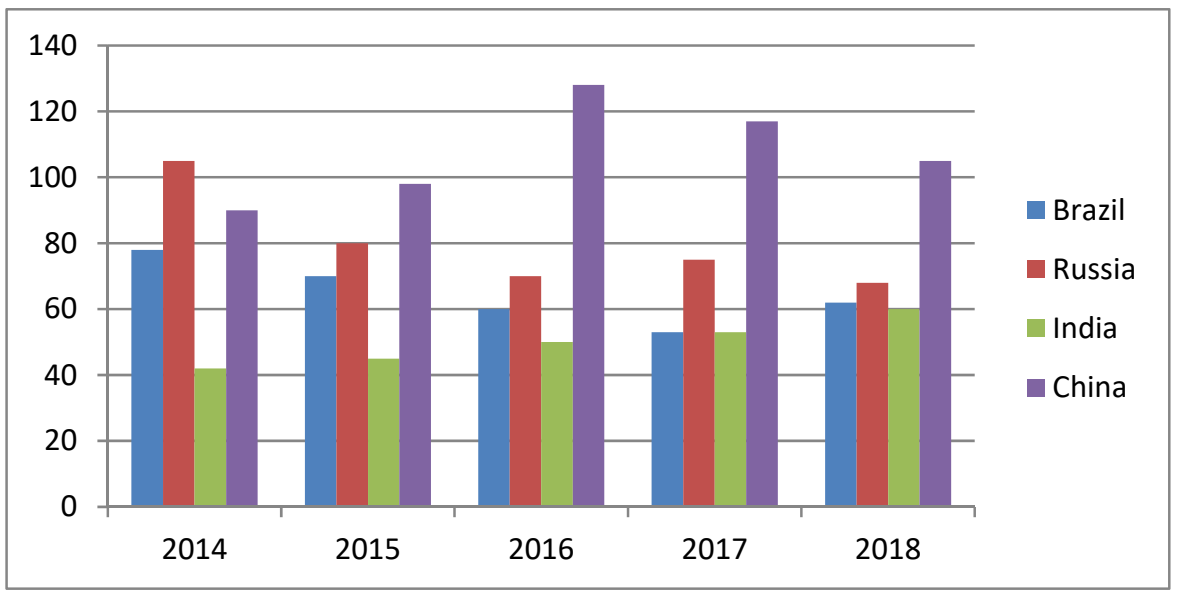

Source: Authors, based on Global Power of Retailing 2016-2020.

Based on the data presented in Figure 2, a relatively growing presence of international retail companies on the markets of BRIC countries can be observed. In this regard, the Chinese market records the largest presence, followed by Russia, Brazil and India. If we look at the growth of international retail companies' presence in 2018, compared to 2014, India records the largest growth with 50\%, while Russia records a decline of $38 \%$. This proves the first hypothesis about the different presence of international retail companies on the markets of BRIC countries. Furthermore, this points to large differences between these markets with one common characteristic - they all belong to a group of emerging markets.

Thus, the Chinese market, with a population of 1.43 billion people, GDP per capita of 18.110 dollars and a total retail turnover of 3.8 billion dollars, makes it the largest world market, but also one of the most attractive emerging markets (A.T. Kearney, GRDI, 2020). Permanent governmental measures of monetary and fiscal policy stimulate the private sector, including retail, so that China is becoming more and more attractive for international retail companies, especially in the last two years. Thus, Aldi, the German retail company, and the American Costco opened their first retail facilities in Shanghai in 2019. Those companies that are already present plan to expand their business on the Chinese market in the years to come, as is the case with American Walmart and Starbucks. 
After two years of pronounced economic depression, Brazil is still facing economic problems. With a population of 211.4 million people, GDP per capita of 16.154 dollars and a total retail turnover of 472.2 billion dollars, it is an attractive market for international retail companies. For example, British retailer WH Smith and French Kiabi opened their retail stores in 2018. Additionally, companies that are already present plan to strengthen their activities, as is the case with the French Casino, which invested additional 464 million dollars in 2018, and Carrefour, which further strengthened its omni-channel capacities.

Despite sanctions and geopolitical tensions, Russia is one of the most attractive markets, with a population of 145.9 million people, GDP per capita of 29.267 dollars and a total retail turnover of 497 billion dollars. Spanish retail chains H\&M and Inditex have the largest retail network, with 139 and 549 facilities throughout Russia, respectively. Of the recognizable retail companies, IKEA, Leroy Merline, Castorama and OBI have the largest presence in Russia.

Owing to the growth of consumer purchasing power and accelerated digitalization, India is becoming more and more interesting for international retail companies, with a population of 1.37 billion people, GDP per capita of 7.874 dollars and total retail turnover of 1.202 billion dollars. Several international retail chains from the luxury products sector, such as Yves Saint Laurent and Tiffany \& Co., have come to India. IKEA, Under Armor, American Eagle Outfitters, Miniso, Ted Baker, Go Sport, Replay and Hummel have the largest presence on the Indian market.

The very market attractiveness is measured in practice by the so-called GRDI (Global Retail Development Index), developed by consultants from A.T. Kearney. It is an average index composed of four variables, which ranks 30 countries in terms of their attractiveness for the arrival of international trading companies (A.T. Kearney, 2020). The index ranges from 0 to 100 , with 0 indicating a high risk, while a score of 100 indicates a low country risk for international trading companies. GRDI is based on the analysis of four variables: market attractiveness, country risk, market saturation and time pressure, where each of these variables is determined based on the analysis of a number of factors.

Market attractiveness, with $25 \%$ share in the assessment of the country's attractiveness, includes the analysis of several variables. First, it estimates per capita sales volume, with a score of 0 indicating that the trade sector is still underdeveloped, while a score of 100 indicates that the market is mature. Second, it assesses population, with a score of 0 indicating that the country is relatively small, with limited growth opportunities. Urban population is in the third place, with a score of 0 indicating that the country is still rural. The fourth to be assessed is business efficiency, with a score of 0 indicating that the country still has poor infrastructure. Fifth, the legal regulations are assessed, which, on the other hand, includes the assessment of the presence of laws, regulation of contracts, tax system efficiency, state intervention in the field of competition, as well as in the field of corporate investment. 
Country risk, with $25 \%$ share in the assessment of the country's attractiveness, includes: political risk, economic performance, country debt, default on loans, volume of loans, access to bank loans, access to short-term funds, access to capital markets and discount for forfeiting. Within the country risk framework, business risk is also assessed, which, on the other hand, includes consideration of the (non) presence of terrorism, crime and violence, irregular payment and corruption.

Market saturation, with $25 \%$ share in the assessment of the country's attractiveness, includes, first of all, the assessment of the share of modern retail. This primarily refers to the presence of modern business formats, with a score of 0 here indicating the presence of modern retail. Then, the number of international retail companies on the existing market is estimated. After that, the market share of modern retail companies is estimated.

Time, with $25 \%$ share in the assessment of the country's attractiveness, shows when it is most convenient to enter the target market. It is viewed on the basis of the analysis of economic development as a whole. This variable ranges from 0 to 100 , with a score of 100 indicating that it is convenient to enter the target market as soon as possible.

The BRIC countries are included in this list, but their position varies from year to year. For the purposes of the analysis in this paper, and based on the mentioned index, we monitor country attractiveness for the period from 2014 to 2018. Tables 1 and 2 point to a comparative analysis of the market attractiveness of Brazil, Russia, India and China.

Table 1. BRIC country ranking by GRDI for 2014-2018

\begin{tabular}{||l|l|l|l|l|l||}
\hline \multirow{2}{*}{ Country } & \multicolumn{5}{|c|}{ Country ranking by GRDI } \\
\cline { 2 - 6 } & $\mathbf{2 0 1 4}$ & $\mathbf{2 0 1 5}$ & $\mathbf{2 0 1 6}$ & $\mathbf{2 0 1 7}$ & $\mathbf{2 0 1 8}$ \\
\hline Brazil & 5 & 8 & 20 & 29 & 16 \\
\hline Russia & 12 & 21 & 22 & 22 & 23 \\
\hline India & 20 & 15 & 2 & 1 & 2 \\
\hline China & 2 & 1 & 1 & 2 & 1 \\
\hline
\end{tabular}

Source: Authors, based on Global retail development index 2014-2018.

Data in Table 1 shows different ranking of Brazil, Russia, India and China in terms of attractiveness for the observed time period, with GRDI in mind. Thus, we see that China has the best position in the analyzed period, considering that in the observed period it is either in the first or second place, and, according to the latest data, it is in the first place in the list of most attractive markets for international retail companies. Unlike China, Brazil significantly worsened its position in the mentioned list, dropping from the fifth place in 2014 to the $29^{\text {th }}$ place in 2017, with the improvement of the position in 2018 , when it came to the $16^{\text {th }}$ place. The deterioration of the position in the list of the most attractive markets is also noted 
in Russia, which came from the $12^{\text {th }}$ position in 2014 to the $23^{\text {rd }}$ position in 2018 . India records the biggest improvement, considering that from the $20^{\text {th }}$ position in 2014, it came to the first place in the list of the most attractive markets in 2017. Judging by the latest 2018 data, India is in the second place, right after China. This proves the second hypothesis about the different attractiveness of BRIC market for the period from 2014 to 2018 .

Table 2. The value of GRDI and its factors for BRIC countries (2014-2018.)

\begin{tabular}{|c|c|c|c|c|c|}
\hline & Year & Brazil & Russia & India & China \\
\hline \multirow[t]{5}{*}{ GRDI score } & 2014 & 60.3 & 52.4 & 45.3 & 64.4 \\
\hline & 2015 & 57.9 & 48.6 & 51.1 & 65.3 \\
\hline & 2016 & 43.0 & 41.8 & 71.0 & 72.5 \\
\hline & 2017 & 39.3 & 43.2 & 71.7 & 70.4 \\
\hline & 2018 & 46.6 & 43.6 & 69.2 & 70.0 \\
\hline \multirow{5}{*}{$\begin{array}{l}\text { Market } \\
\text { attractiveness }\end{array}$} & 2014 & 99.4 & 94.0 & 26.4 & 60.9 \\
\hline & 2015 & 98.0 & 94.9 & 30.5 & 66.7 \\
\hline & 2016 & 85.9 & 93.6 & 53.7 & 100.0 \\
\hline & 2017 & 70.5 & 79.6 & 63.4 & 100.0 \\
\hline & 2018 & 65.5 & 79.8 & 60.2 & 100.0 \\
\hline \multirow[t]{5}{*}{ Country risk } & 2014 & 59.8 & 38.4 & 39.0 & 52.5 \\
\hline & 2015 & 60.4 & 28.4 & 39.8 & 55.7 \\
\hline & 2016 & 65.7 & 26.6 & 54.3 & 61.2 \\
\hline & 2017 & 63.8 & 28.2 & 59.1 & 64.5 \\
\hline & 2018 & 67.4 & 36.0 & 60.9 & 72.7 \\
\hline \multirow{5}{*}{$\begin{array}{l}\text { Market } \\
\text { saturation }\end{array}$} & 2014 & 48.7 & 30.7 & 72.3 & 44.5 \\
\hline & 2015 & 45.2 & 24.5 & 75.7 & 42.3 \\
\hline & 2016 & 20.4 & 6.1 & 75.8 & 36.2 \\
\hline & 2017 & 23.1 & 3.6 & 75.7 & 24.4 \\
\hline & 2018 & 25.4 & 0 & 66.8 & 18.9 \\
\hline \multirow{5}{*}{$\begin{array}{l}\text { Time } \\
\text { pressure }\end{array}$} & 2014 & 33.2 & 45.4 & 43.4 & 100.0 \\
\hline & 2015 & 28.0 & 46.6 & 58.5 & 96.6 \\
\hline & 2016 & 0 & 40.9 & 100.0 & 92.5 \\
\hline & 2017 & 0 & 61.3 & 88.5 & 92.5 \\
\hline & 2018 & 28.1 & 58.8 & 88.8 & 88.9 \\
\hline
\end{tabular}

Source: Authors, based on Global retail development index 2014-2018. 
Such market positions of BRIC countries are the result of various factors. Since the value of GRDI, according to the A.T. Kearney methodology, is based on the values of market attractiveness, country risk, market saturation and time pressure, it varies by years and by observed countries, which is presented in Table 2 .

Furthermore, in order to connect the phenomenon of market attractiveness for entry, expressed by ranking in the list of countries, and the number of international retail companies operating in these countries, we construct simple regression models for each country, to test the third research hypothesis. In these models, the dependent variable is the number of international retail companies, while market attractiveness, i.e. country ranking, is independent variable. The results are shown in Figures 3 to 6 .

Figure 3. Number of international retail companies depending on market attractiveness, i.e. country ranking in the period 2014-2018 - the case of Brazil

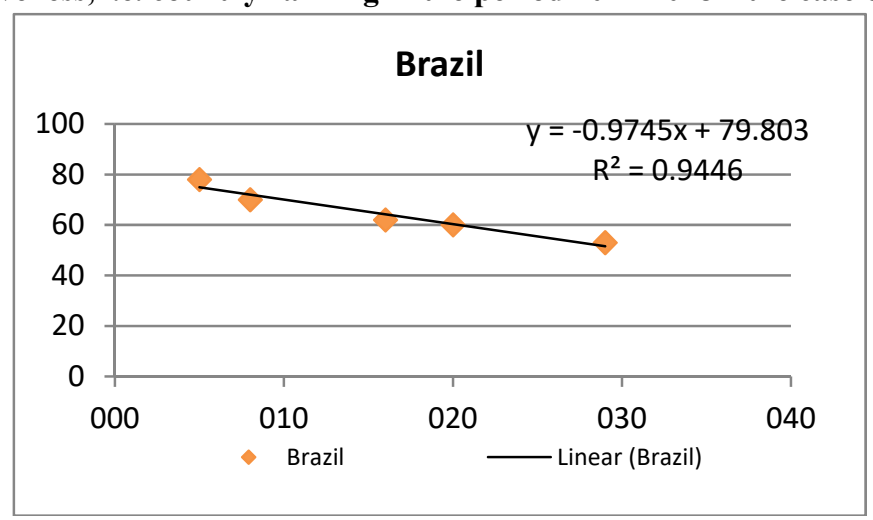

Source: Authors

Figure 4. Number of international retail companies depending on market attractiveness, i.e. country ranking in the period 2014-2018 - the case of Russia

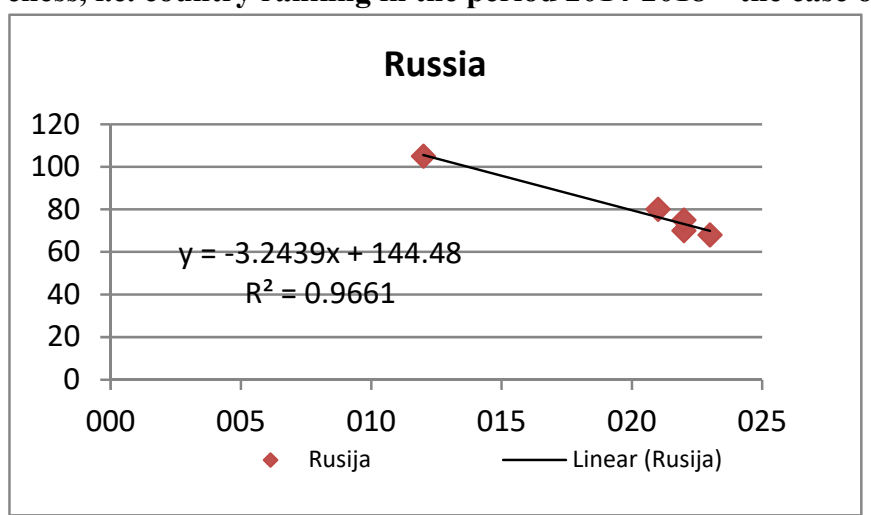

Source: Authors 
Figure 5. Number of international retail companies depending on market attractiveness, i.e. country ranking in the period 2014-2018 - the case of India

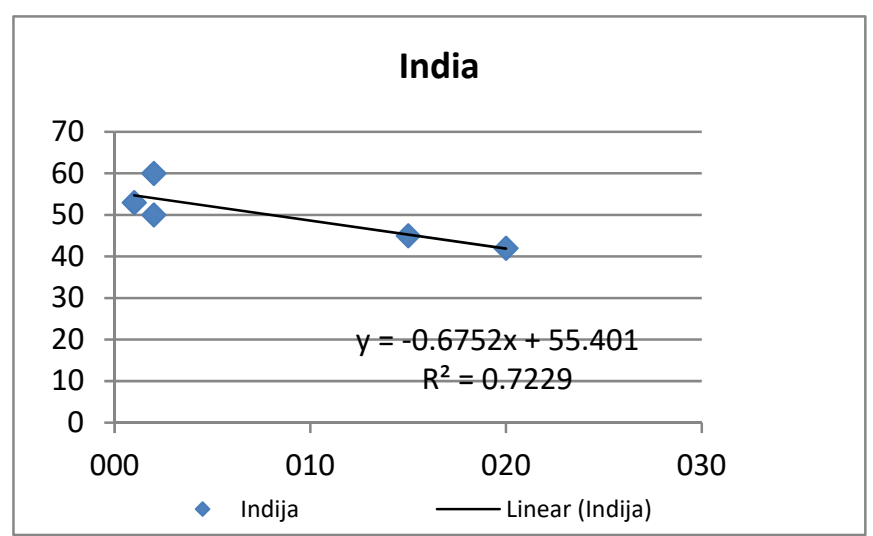

Source: Authors

Figure 6. Number of international retail companies depending on market attractiveness, i.e. country ranking in the period 2014-2018 - the case of China

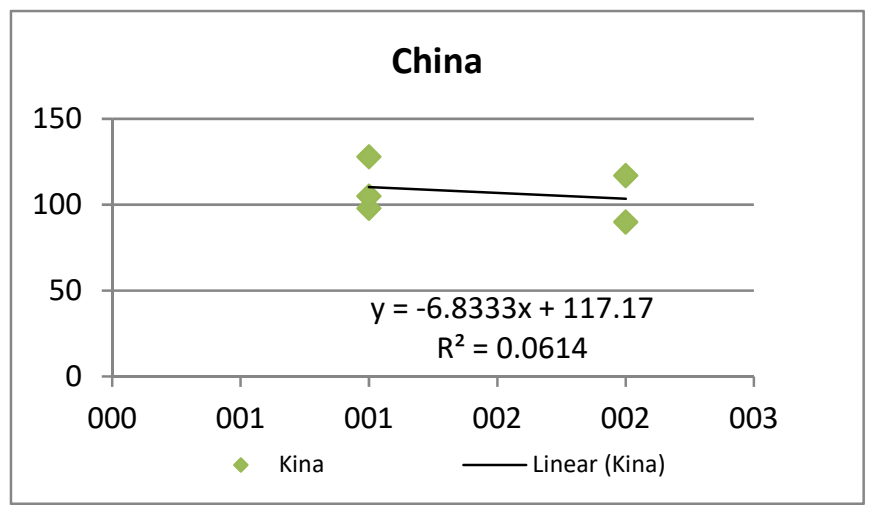

Source: Authors

The results of a simple regression analysis, with a high coefficient of determination, point to the conclusion that the country ranking, from the point of view of market attractiveness, is a determinant of the number of international retail companies operating in that country. ${ }^{3}$ This proves the third research hypothesis.

According to the A.T. Kearney methodology, all the mentioned factors have the same share $(25 \%)$ in the total value of GRDI. However, Table 2 shows their

${ }^{3}$ The exception is China, whose coefficient of determination $\left(\mathrm{R}^{2}\right)$ is less than 0.5 , which is a direct consequence of the fact that China has not changed its position significantly, and the number of international retail companies has fluctuated in the observed period. 
different values, by country and by year. This indicates the different influences of these factors on the ranking of BRIC countries in the list of the most attractive markets, used to test the fourth hypothesis set out in this paper.

To that end, descriptive statistics is made, with an analysis of the correlation between the country ranking and the mentioned factors. The results of descriptive statistics for each country are presented in Tables 3 to 6 .

Table 3. The value of the Pearson correlation coefficient and the level of statistical significance of market attractiveness in relation to the country ranking - the case of Brazil

\begin{tabular}{|l|l|r|r|r|r|r||}
\hline \multicolumn{2}{|c|}{} & \multicolumn{1}{c|}{ Rank } & \multicolumn{1}{c|}{ MA } & \multicolumn{1}{c|}{ CR } & \multicolumn{1}{c|}{ MS } & \multicolumn{1}{c|}{ TP } \\
\hline $\begin{array}{l}\text { Pearson } \\
\text { Correlation }\end{array}$ & Rank & 1,000 &,- 760 &, 588 &,- 875 &,- 876 \\
\cline { 2 - 7 } & MA &,- 760 & 1,000 &,- 844 &, 810 &, 399 \\
\cline { 2 - 7 } & CR &, 588 &,- 844 & 1,000 &,- 875 &,- 393 \\
\cline { 2 - 7 } & MS &,- 875 &, 810 &,- 875 & 1,000 &, 783 \\
\cline { 2 - 7 } & TP &,- 876 &, 399 &,- 393 &, 783 & 1,000 \\
\hline \multirow{5}{*}{ Sig. (1-tailed) } & Rank & &, 068 &, 149 &, 026 &, 026 \\
\cline { 2 - 7 } & MA &, 068 & &, 036 &, 048 &, 253 \\
\cline { 2 - 8 } & CR &, 149 &, 036 & &, 026 &, 256 \\
\cline { 2 - 8 } & MS &, 026 &, 048 &, 026 & &, 059 \\
\cline { 2 - 8 } & TP &, 026 &, 253 &, 256 &, 059 & \\
\hline
\end{tabular}

Source: Authors

Table 4. The value of the Pearson correlation coefficient and the level of statistical significance of market attractiveness in relation to the country ranking - the case of Russia

\begin{tabular}{||l|l|r|r|r|r|r||}
\hline \multicolumn{2}{|c|}{} & \multicolumn{1}{c|}{ Rank } & \multicolumn{1}{c|}{ MA } & \multicolumn{1}{c|}{ CR } & \multicolumn{1}{c|}{ MS } & \multicolumn{1}{c|}{ TP } \\
\hline \multirow{4}{*}{$\begin{array}{l}\text { Pearson } \\
\text { Correlation }\end{array}$} & Rank & 1,000 &,- 529 &,- 613 &,- 811 &, 379 \\
\cline { 2 - 7 } & MA &,- 529 & 1,000 &,- 108 &, 783 &,- 947 \\
\cline { 2 - 7 } & CR &,- 613 &,- 108 & 1,000 &, 296 &, 174 \\
\cline { 2 - 7 } & MS &,- 811 &, 783 &, 296 & 1,000 &,- 561 \\
\cline { 2 - 8 } & TP &, 379 &,- 947 &, 174 &,- 561 & 1,000 \\
\hline \multirow{4}{*}{ Sig. (1-tailed) } & Rank & &, 180 &, 136 &, 048 &, 265 \\
\cline { 2 - 8 } & MA &, 180 & &, 431 &, 059 &, 007 \\
\cline { 2 - 8 } & CR &, 136 &, 431 & &, 314 &, 390 \\
\cline { 2 - 8 } & MS &, 048 &, 059 &, 314 & &, 163 \\
\cline { 2 - 8 } & TP &, 265 &, 007 &, 390 &, 163 & \\
\hline
\end{tabular}

Source: Authors 
Table 5. The value of the Pearson correlation coefficient and the level of statistical significance of market attractiveness in relation to the country ranking - the case of India

\begin{tabular}{||l|l|r|r|r|r|r||}
\hline \multicolumn{2}{|c|}{} & \multicolumn{1}{c|}{ Rank } & \multicolumn{1}{c|}{ MA } & \multicolumn{1}{c|}{ CR } & \multicolumn{1}{c|}{ MS } & \multicolumn{1}{c|}{ TP } \\
\hline $\begin{array}{l}\text { Pearson } \\
\text { Correlation }\end{array}$ & Rank & 1,000 &,- 977 &,- 959 &, 130 &,- 973 \\
\cline { 2 - 7 } & MA &,- 977 & 1,000 &, 992 &,- 227 &, 905 \\
\cline { 2 - 8 } & CR &,- 959 &, 992 & 1,000 &,- 333 &, 886 \\
\cline { 2 - 8 } & MS &, 130 &,- 227 &,- 333 & 1,000 &,- 043 \\
\cline { 2 - 8 } & TP &,- 973 &, 905 &, 886 &,- 043 & 1,000 \\
\hline \multirow{5}{*}{ Sig. (1-tailed) } & Rank & &, 002 &, 005 &, 418 &, 003 \\
\cline { 2 - 8 } & MA &, 002 & &, 000 &, 357 &, 017 \\
\cline { 2 - 8 } & CR &, 005 &, 000 & &, 292 &, 023 \\
\cline { 2 - 8 } & MS &, 418 &, 357 &, 292 & &, 472 \\
\cline { 2 - 8 } & TP &, 003 &, 017 &, 023 &, 472 & \\
\hline
\end{tabular}

Source: Authors

Table 6. The value of the Pearson correlation coefficient and the level of statistical significance of market attractiveness in relation to the country ranking - the case of China

\begin{tabular}{||l|l|r|r|r|r|r||}
\hline \multicolumn{2}{|c|}{} & \multicolumn{1}{c|}{ Rank } & \multicolumn{1}{c|}{ MA } & \multicolumn{1}{c|}{ CR } & \multicolumn{1}{c|}{ MS } & \multicolumn{1}{c|}{ TP } \\
\hline $\begin{array}{l}\text { Pearson } \\
\text { Correlation }\end{array}$ & Rank & 1,000 &,- 233 &,- 325 &, 096 &, 480 \\
\cline { 2 - 7 } & MA &,- 233 & 1,000 &, 858 &,- 821 &,- 908 \\
\cline { 2 - 7 } & CR &,- 325 &, 858 & 1,000 &,- 967 &,- 966 \\
\cline { 2 - 7 } & MS &, 096 &,- 821 &,- 967 & 1,000 &, 895 \\
\cline { 2 - 7 } & TP &, 480 &,- 908 &,- 966 &, 895 & 1,000 \\
\hline \multirow{5}{*}{ Sig. (1-tailed) } & Rank & &, 353 &, 297 &, 439 &, 206 \\
\cline { 2 - 7 } & MA &, 353 & &, 031 &, 044 &, 016 \\
\cline { 2 - 7 } & CR &, 297 &, 031 & &, 004 &, 004 \\
\cline { 2 - 7 } & MS &, 439 &, 044 &, 004 & &, 020 \\
\cline { 2 - 7 } & TP &, 206 &, 016 &, 004 &, 020 & \\
\cline { 2 - 7 } & & & & & &
\end{tabular}

Source: Authors

The results obtained by descriptive statistics confirm the fourth hypothesis. Specifically, the markets of BRIC countries have different degrees of attractiveness in the analyzed time interval and, additionally, different factors affect the attractiveness of BRIC countries for international retail companies. For example, in the case of Brazil, the factors that are crucial to the country's ranking, and, thus, to its attractiveness for international retail companies in the analyzed period are market saturation (MS) and time penetration (TP). These two factors have a statistical significance greater than $95 \%$ and a Pearson correlation coefficient value 
of almost -0.9. This means that the improvement of these factors (their higher absolute value) leads to a better positioning of Brazil in the list of the most attractive markets for international retail companies (lower absolute value).

In the case of Russia, the factor that is of crucial importance for the country ranking, and, thus for its attractiveness for international retail companies in the analyzed period, is market saturation (MS). This factor has a statistical significance greater than $95 \%$ and the value of Pearson's correlation coefficient of -0.81 . This means that the improvement of this factor (its higher absolute value) leads to a better positioning of Russia in the list of the most attractive markets for international retail companies (lower absolute value).

In the case of India, the factors that are crucial for the country's ranking, and, thus, for its attractiveness for international retail companies in the analyzed period are market attractiveness (MA), country risk (CR), and time penetration (TP). These three factors have a statistical significance greater than $95 \%$ and a Pearson correlation coefficient value of almost -0.95 . This means that the improvement of these factors (their higher absolute value) leads to a better positioning of India in the list of the most attractive markets for international retail companies (lower absolute value).

In the case of China, there were no significant changes in the country ranking from the point of view of attractiveness for international retail companies, so the obtained data has no statistical significance and it is impossible to draw a conclusion.

This research, and, therefore, the results obtained, should be taken with certain limitations. The limitation refers to the fact that the conclusions are valid only for the analyzed time period, which is extremely short. However, despite the small number of observations, the conclusions have economic validity for the purposes of statistical analysis, i.e. factors included in country attractiveness have a different impact on the number of international retail companies.

\section{Conclusion}

The results obtained by the research in this paper confirm the growing importance of the emerging markets, both in terms of theory and in terms of company operations in different sectors. In the theoretical part of the paper, the key theoretical contributions to the definition of the emerging markets, their characteristics, as well as different approaches to this issue are pointed out. Also, the key theoretical contributions to the issue of retail internationalization are highlighted. In order to test the set hypotheses, the research was conducted, based on the available secondary data sources, consisting of reports on the largest retail companies in the period from 2014 to 2018, as well as reports on the most attractive markets in the same period. The methods of simple regression analysis 
and descriptive statistics prove that the attractiveness of BRIC countries for international retail companies, measured by their position in the list of the most attractive markets using the so-called GRDI (Global Retail Development Index), is a determinant of the number of international retail companies in the period from 2014 to 2018. On the other hand, there are various factors that affect the attractiveness of BRIC countries for international retail companies. For example, in the case of Brazil, these are market saturation (MS) and time penetration (TP). In the case of India, these are market attractiveness (MA), country risk (CR), and time penetration (TP). In the analyzed period, China did not identify factors with statistical significance, while in the case of Russia, market saturation (MS) is a crucial factor for positioning in the list of the most attractive markets. The results obtained can serve as a guide for managers in making a decision on a market for expanding retail operations. They can serve as a basis for theorists for further research on this current issue, given that the results obtained have certain limitations, which primarily relate to the number of observations, but also a short period of observation. Given the current moment, with dramatic changes in the world economy caused by the global coronavirus pandemic, the research of relations between the emerging markets and retail internationalization will face numerous challenges and dilemmas. The issue of the emerging market attractiveness for international retail companies will be analyzed using complex approaches and methods, from the point of view of a country's readiness and ability to respond to the challenges of the global pandemic crisis and adequately mitigate its consequences.

\section{References}

A.T. Kearney (2020), Global retail development index 2014-2018, retrieved from: https://www.kearney.com/global-retail-development-index. Accessed June 1, 2020.

Alexander, N. \& Doherty, A. (2010). International retail research: focus, methodology and conceptual development. International Journal of Retail \& Distribution Management, 38 (11/12), 928-942.

Alexander, N. \& Doherty, A. (2009). International retailing. London: Oxford University press.

Alexander, N., Rhodes, M. \& Myers, H. (2011). A gravitational model of international retail market selection. International Marketing Review, 28 (2), 183-200.

Alon, I., Lattemann, C., Fetscherin, M., Li, S. \& Schneider, A.-M. (2010). Usage of public corporate communications of social responsibility in Brazil, Russia, India and China (BRIC). International Journal of Emerging Markets, 5, 6-22.

Amine, A. \& Lazzaoui, N. (2011). Shoppers' reactions to modern food retailing systems in an emerging country - The case of Morocco. International Journal of Retail \& Distribution Management, 39 (8), 562-581.

Arnold, D.J. \& Quelch, J.A. (1998). New strategies in emerging markets. MIT Sloan Management Review, 40 (1), 7-20. 
Aulakh, P.S., Kotabe, M. \& Teegen, H. (2000). Export strategies and performance of firms from emerging economies: Evidence from Brazil, Chile, and Mexico. Academy of Management Journal, 43 (3), 342-361.

Bianchi, C. (2009). Retail internationalisation from emerging markets: case study evidence from Chile. International Marketing Review, 26 (2), 221-243.

Burt, S., Johansson, U. \& Dawson, J. (2016). International retailing as embedded business models. Journal of Economic Geography, 16 (3), 715-747.

Corporate Finance Institute (2020). Emerging Markets, retrieved from: https://corporatefinanceinstitute.com/resources/knowledge/economics/emergingmarkets/. Accessed June 5, 2020.

Ćuzović, S., Sokolov Mladenović, S., Ćuzović, Đ. (2015) Menadžment internacionalizacije trgovine. Niš: Ekonomski fakultet.

Ćuzović, S., Sokolov Mladenović, S. \& Ćuzović, Đ. (2019). The impact of social and cultural factors on success of trade internationalization. Poslovna izvrsnost, 13 (1), 57-76.

Dawson, J. A. (2007). Scoping and conceptualizing retailer internationalization. Journal of Economic Geography, 7 (4), 373-397.

Diallo, M.F. \& Siqueira, J.R. (2017). How previous positive experiences with store brands affect purchase intention in emerging countries - A comparison between Brazil and Colombia. International Marketing Review, 34 (4), 536-558.

Dimitrova, B. V., Rosenblooma, B., Andrasa, T.L. \& Kimb, S. (2018). Retail internationalization: A review and directions for future research. Journal of marketing channels, 25 (1-2), 1-21.

Deloite Touche (2020). Global Power of Retailing 2016-2020, retrieved from: https://www2.deloitte.com/global/en/pages/consumer-business/articles/global-powersof-retailing.html. Accessed 15 June, 2020.

Gomez, R.M., Carneiro, J. \& Dib, L.A. (2018). Branded retailer expansion on a continent-sized emerging market. International Journal of Retail \& Distribution Management, 46 (9), 820-834.

Hoskisson, R.E., Eden, L., Lau, C.M. \& Wright, M. (2000). Strategy in emerging economies. Academy of Management Journal, 43 (3), 249-267.

$\mathrm{Hu}$, L. (2018). The Chinese market as an opportunity to innovate distribution strategies? Evidences from Italian firms. European Business Review, 30 (5), 607-626.

Iwasaki, I. (2020). Meta-Analysis of Emerging Markets and Economies: An-Introductory Note for the Special Issue. Emerging Markets Finance \& Trade, 56, 1-9.

Khanna, T. \& Palepu, K. (1997). Why focused strategies may be wrong for emerging markets. Harvard Business Review, 75, 41-51.

Meyer, K.E., Estrin, S., Bhaumik, S.K. \& Peng, M.W. (2009). Institutions, resources, and entry strategies in emerging economies. Strategic Management Journal, 30 (1), 61-80.

Mohr, A. \& Batsakis, G. (2014). Intangible assets, international experience and the internationalization speed of retailers. International Marketing Review, 31 (6), 601-620.

MSCI (2020). MSCI Emerging Markets Index (USD), retrieved from: https://www.msci.com/documents/10199/c0db0a48-01f2-4ba9-ad01-226fd5678111. Accessed June 10, 2020.

O'neill, J. (2001). Building better global economic BRICs. Global Economics, 30, 20-30.

Paul, J. (2015). Market access and the mirage of marketing to the maximum: new measures. Asia Pacific Journal of Marketing and Logistics, 27 (4), 676-688. 
Paul, J. (2020). Marketing in emerging markets: a review, theoretical synthesis and extension. International Journal of Emerging Markets, 15 (3), 446-468.

Paul, J. \& Benito, G.R. (2018). A review of research on outward foreign direct investment from emerging countries, including China: what do we know, how do we know and where should we be heading? Asia Pacific Business Review, 24 (1), 90-115.

Peng, M.W. (2003). Institutional transitions and strategic choices. Academy of Management Review, 28 (2), 275-296.

Pederzoli, D. \& Kuppelwieser, V.G. (2015). Retail companies' internationalization behavior and the 2008 crisis. International Journal of Retail \& Distribution Management, 43 (9), 870894.

Sandberg, S. (2014). Experiential knowledge antecedents of the SME network node configuration in emerging market business networks. International Business Review, 23 (1), 20-29.

Siegel, J. (2009). Is there a better commitment mechanism than cross-listings for emergingeconomy firms evidence from Mexico? Journal of International Business Studies, 40 (7), 1171-1191.

The World Bank (2020). World Bank Country and Lending Groups, retrieved from: https://datahelpdesk.worldbank.org/knowledgebase/articles/906519. Accessed June 10, 2020.

Van Agtmael, A. (2007). The Emerging Markets Century: How a New Breed of World-Class Companies is Overtaking the World. New York: Simon and Schuster.

Vida, I. \& Fairhurst, A. (1998). International expansion of retail firms: a theoretical approach for future investigations. Journal of Retail and Consumer Services, 5 (3), 143-151.

Wright, M., Filatotchev, I., Hoskisson, R.E. \& Peng, M.W. (2005). Strategy research in emerging economies: challenging the conventional wisdom. Journal of Management Studies, 42 (1), 1-33.

\section{TRŽIŠTA U NASTAJANJU I INTERNACIONALIZACIJA MALOPRODAJE: SLUČAJ ZEMALJA BRIC-A}

Apstrakt: Osnovna svrha ovog rada je da istraži odnos između tržišta u nastajanju i internacionalizacije maloprodaje, s posebnim fokusom na tržišta zemalja Brazila, Rusije, Indije i Kine, poznata kao BRIC. U radu se polazi od činjenice da tržišta u nastajanju, posebno tržišta zemalja BRIC-a, poslednjih godina privlače sve veću pažnju naučno-stručne javnosti, ali i internacionalnih maloprodajnih kompanija. Internacionalizacija maloprodaje, kao ključna strategija poslovanja, menja svoj pravac, ali i obrazac, nakon ekonomske krize 2008. godine i fokusira se na tržišta u nastajanju. Na bazi razpoloživih sekundarnih izvora podataka o poslovanju najvećih internacionalnih maloprodajnih kompanija i atraktivnosti tržišta u nastajanju, u vremenskom intervalu od 2014. do 2018. godine, testirane su hipoteze postavljene u ovom istraživanju. Jedna od ključnih hipoteza jeste da je broj prisutnih internacionalnih maloprodajnih kompanija na tržištu zemlje BRIC-a determinisan njenim rangom na listi najatraktivnijih tržišta. Ova hipoteza je testirana konstruisanjem prostog regresionog modela za svaku zemlju ponaosob. Druga ključna hipoteza jeste da je rangiranje zemlje BRIC-a na listi najatraktivnijih tržišta rezultat dejstva različitih faktora. Ova 
hipoteza je testirana primenom metoda deskriptivne statistike za svaku zemlju ponaosob. Dobijeni rezultati istraživanja imaju ekonomsku validnost i popunjavaju naučnu nišu u istraživanjima odnosa atraktivnosti tržišta zemalja BRIC-a i internacionalizacije maloprodaje. Dodatno, dobijeni rezultati predstavljaju osnov za dalja istraživanja ove problematike, imajući u vidu da se u aktuelnom trenutku dešavaju ogromne promene izazvane svetskom pandemijom koronavirusa.

Ključne reči: tržišta u nastajanju, BRIC, internacionalizacija maloprodaje, GRDI, atraktivnost tržišta, rizik (zemlje), zasićenje tržišta.

\section{Authors' biographies}

Svetlana Sokolov Mladenović, $\mathrm{PhD}$, is an associate professor at the Faculty of Economics, University of Niš. She teaches at bachelor studies (subjects: Economics of Trade and Trade Management), master studies (subject: Trade Management and Internationalization of Retail), as well as $\mathrm{PhD}$ studies (subject: Strategy and politic of trade development). Her research is focused on trade, trade policy, trade management, trade marketing, as well as retail internationalization and e-commerce. She has published two monographs, more than 100 papers in scientific and professional journals. She has participated in many research conferences at home and abroad. She is an member of the Serbian marketing association (SEMA).

Igor Mladenović, $\mathrm{PhD}$, is full professor at the Faculty of Economics, University of Niš. He teaches at bachelor studies (subjects: Macroeconomics and Capital economics and financing economic development), master studies (subject: Macroeconomics of open economy), as well as $\mathrm{PhD}$ studies (subject: Macroeconomics and macro management). His research is focused on macroeconomics, economic development, economic growth, as well as financing of economic development. He has published two monographs, more than 100 papers in scientific and professional journals. He has participated in many research conferences at home and abroad. Also, he is a head of the several projects realized by University in Niš.

Marija Petrović Ranđelović, PhD, is full professor at the Faculty of Economics, University of Niš. She teaches National Economics and Economic Policy at undergraduate studies, Economic of Sustainable Development at master studies and Economic Development Strategies at $\mathrm{PhD}$ studies. She earned her MA in Economics from Faculty of Economics, University of Belgrade in 2005. She defended doctoral dissertation entitled "The impact of foreign direct investment on the environmental component of sustainable development" at Faculty of Economics, University of Niš in 2009. Her areas of expertise are: Foreign Direct Investments, Economic Development and Economic Policy. 